\title{
MADRASAH SEBAGAI LEMBAGA PENDIDIKAN ISLAM
}

\section{INDONESIA}

\author{
ADEK KHOLIJAH SIREGAR, M.Pd.I
}

( Dosen PIAUD Fakultas Agama Islam, UMTS )

\begin{abstract}
Madrasah is one of the educational institutions in Indonesia that has an important role in the development of Madrasah education is generally established by the community, where the managers and support communities that determine the vision and mission whether the educational institutions have a desire to move forward. Madrasah is also a kind of education that gives attention and once makes the teachings of Islam as knowledge for the study program that held it.

Madrasahs are educational institutions born from, and to the community. Complaints about the quality of education in madrasah are always not about lack of religious education, but rather the lack of general education that is not commensurate with public schools and has no social effect in society.
\end{abstract}

Keywords: Madrasah, Islamic Education Agency

\section{A. LATAR BELAKANG}

Madrasah dari aspek derivasi kata merupakan ism makan dari darasa yang berarti belajar. Jadi madrasah berarti tempat belajar bagi siswa atau mahasiswa. Istilah madrasah ini sekarang telah menyatu dengan istilah sekolah atau perguruan.

Dalam khazanah pendidikan islam, sejarah perkembangan madrasah akan selalu menjadi kajian menarik untuk terus di analisis secara krits. Kajian kriti ini menjadi sangat urgenth karena di nilai akan dapat menempatkan madrasah dalam sejarah perkembangan pendidikan dan intelektual muslim secara lebih objektif dan komprehensif. Dengan demikian, di harapkan akan di peroleh gambaran yang semestinya tentang keberadaan madrasah berikut peran dan kontribusinya, jauh dari gambaran ideal yang bersifat palsu dan subjektif.

Dalam catatan sejarah peradaban islam diketahui bahwa islam (di timur tengah) pada akhir abad VIII, ketika Harun Al-Rasyid memerintah di bagdad (789-809 M) islam telah menikmati suatu peradaban budaya 
yang jauh lebih tinggi dengan eropa barat. Ini bertahan selama lima ratus tahun ( dari abad VIII sampai abad XIII), dengan hasil kebudayaan ilmu, ilmu pengetahuan, seni, dan pemikiran terbukti telah memengaruhi kebudayaan dunia. Salah satu kemajuan yang patut di banggakan adalah adanya pendirian madrasah sebagai institusi pendidikan islam yang memiliki kontribusi besar dalam melahirkan atau " memberikan bekal" kepada kaum cendekiawan, terpelajar, negarawan, dan adminstrator.

Kajian tentang madrasah oleh sebagai peneliti, selama ini masih berkutat pada aspek madrasah sebagai institusi pendidikan islam dilihat dari aspek historis, namun kajian yang di kaitkan dengan aspek sosial bisa dikatakan masih kurang. Padahal eksistensi madrasah baik pada abad klasik sampai abad XXI (saat ini) tidak jauh berbeda. Dinamika madrasah yang tumbuh dan berakar dari kultur masyarakat setempat tidak akan luput dari dinamika sdan peradaban masyarakat ( change of society).

Madrasah mulai didirikan dan berkembang pada abad ke-5 $\mathrm{H}$ atau abad ke-10 atau ke -11 M. Pada masa itu ajaran agama islam telah berkembanag secara luas dalam berbagai macambidang ilmu pengetahuan, dengan berbagai macam mazhab atau pemikiranya, berbagai ilmu pengetahuan.

\section{B. . KELAHIRAN MADRASAH DI DUNIA ISLAM}

Madrasah merupakan isim makan dari "darasa " yang berarti “ tempat duduk untuk belajar". Istilah madrasah ini sekarang telah menyatu dengan istilah sekolah atau perguruan ( terutama islam ) ( MS. Poerwadarminta, 1990: 618). Sementara itu, Karel A. Steenbrink justru membedakan antara madrasah-madrasah dengan sekolah-sekolah, dan beralasan bahwa sekolah dam madrasah mempunyai ciri yang berbeda. Meskipun demikian, konteks tulisan disini cenderung menyamakan atri madrasah dengan sekolah.

Madrasah sebagai pendidikan islam, mulai didirikan dan berkembang di dunia islam sekitar abad ke $-5 \mathrm{H}$ atau abad ke-10 M. Ketika penduduk Naisabur mendirikan lembaga pendidikan islam model 
madrasah tersebut untuk pertama kalinya( Moh. Athiyah al- abrasyi, 1974:82). ${ }^{1}$

Pada zaman pemerintahan bani umayyah, ummat islam sudah mempunyai semacam lembaga pendidikan Islam yang di sebut "kuttab". Para guru yang mengajar di kuttab ini pada mulanya adalah orang-orang non-muslim, terutama orang-orang yahudi dan nasrani. Karena itulah, bagi ummat islam, pengajaran kuttab itu hanya sebagai tempat belajar keterampilan membaca dan, menulis saja, sedangkan pengajaran al-quran dan dasar agama islam di berikan dan di ajarkan di masjid-masjid oleh para guru khusus. Selanjutnya, untuk kepentingan pengajaran menulis dan membaca bagi anak-anak, yang sekali gus juga memberikan pelajaran alquran dan dasar-dasar pengetahuan agama islam, di adakanlah kuttabkuttab yang terpisah dari masjid agar anak-anak tidak menggangu ketenangan dan kebersihan masjid.

Pada awal perkembangan pendidikan islam telah terdapat dua jenis lembaga pendidikan dan pengajaran, yaitu: kuttab yang mengajarkan kecakapan menulis dan membaca al-quran serta dasar-dasar agama islam kepada anak-anak dan merupakan pendidikan tingkat dasar. sedangkan di masjid dalam bentuk halaqah, yang memberikan pendidikan dan pengajaran tentang berbagai macam ilmu.

Lahirnya madrasah-madrasah di dunia islam, pada dasarnya merupakan usaha pengembangan dan penyempurnaan zawiyah-zawiyah tersebut, dalam rangka menampung pertumbuhan dan perkembangan dan jumlah pelajar yang semakin meningkat yang berlangsung sampai sekarang. Sementara itu Karel A. Membedakan antara madrasah dan sekolah-sekolah, dia beralasan bahwa antar sekolah dan madrasah mempunyai ciri yang berbeda. Maskipun demikian, dalam konteks ini cenderung menyamakan madrasah dengan sekolah.

\section{LAHIR DAN BERKEMBANGYA MADRASAH DI INDONESIA}

\footnotetext{
${ }^{1}$ Dra. Hj. Enung K Rukianta, Sejarah Pendidikan Islam, (Bandung: CV pustaka setia,2006), hlm.113
} 
Kehadiran madrasah sebagai lembaga pendidikan islam setidaktidaknya mempunyai beberapa latar belakang, di antaranya:

1. Sebagai manifestasi dan realisasi pembaharuan sistem pendidikan islam.

2. Usaha penyempurnaan terhadap sistem pendidikan yang lebih memingkinkan lulusanya memperoleh kesempatam yang sama dengan sekolah umum, misalnya masalah kesamaan kesempatan kerja dan perolehan ijazah.

3. Adanya sikap mental pada sementara golongan ummat islam, khususnya santri yang terpukau pada barat sebagai sistem pendidikan modren dari hasil akulturasi.

Ada juga faktor yang melatar belakangi lembaga pendidikan islam yang ada di indonesia, sekitar permulaan abad ke-20, dan secara garis besar di kelompokkan kepada dua hal yaitu: keadaan bangsa indonesia dan faktor kondisi luar negeri.

1. Keadaan bangsa indonesia

a. Segi ajaran islam

Islam masuk ke indonesia sekitar abad 7-8M. Kondisi ummat dan ajaran islam yang ada di indonesia berbeda dengan negara-negara islam lainya. Sebelum islam datang, di indonesia sudah terbentuk pola-pola kebudayaan non-muslim, terutama hindu dan budha, termasuk animisme dan dinamisme. Jadi islam masuk ke nusantara tidak dalam kondisi vakum kultural atau vakum peradaban.

Oleh karena itu proses akulturasi pola-pola kebudayaan dan bentuk-bentuk kepercayaan antara islam dan non-islam terjadi sepenuhnya. b. Aktifitas lembaga pendidikan islam

Tidak bisa di pungkiri bahwa sistem pendidikan dan pengajaran islam pada masa lalu, terutama pesantrean yang bersifat tradisional masih terdapat banyak kelemahan, terutama menyangkut sistem yang terdapat di dalamya. 
Namun demikian, peran pesantren dalam rangka mencerdaskan kehidupan bangsa tidaklah di ragukan dan pesantren merupakan satisatunya lembaga pendidikan yang ada pada waktu itu(sebelum abad ke20).

Pada awal ke-20, sistem pendidikan model madrasah bermunculan, sebagaimana halnya pesantren. Kemunculan madrasah ini minimal dapat di lihat dari dua sisi. Pertama, ia sebagai salah satu bentuk pengembangan yang berasal dari pesantren. Kedua madrasah lahir dari luar pesanteren, seperti organisasi sosial keagaman atau organisasi sosial politik. Dalam konteks ini kelahiran madrasah bukan merupakan kelanjutan dari sistem pesanteren, melainkan sistem pendidikan yang berdiri sendiri. Madrasah yang lahir dari luar pesanteren dan organisasi sosial keagamaan lebih banyak muncul diluar.

Diantara madrasah yang bermunculan saat itu madrsah Adabiyah merupakan madrasah pertama kali didirikan di indonesia(1909). Pda tahun 1910, berdiri madrasah Muhammadiyah, yang kemudian berubah menjadi madrasah Mu' allimim Muhammadiyah yang berdiri di Yogyakarta tahun 1911yang di pelopori oleh KH. Ahmad Dahlan. Dari pesanteren Tebu Ireng berdiri madrasah Salafiyah tahun $1916 .^{2}$

2. Faktor kondisi luar negeri

Keberadaan dunia islam terutama abad ke-19 sebagian besar berada di bawah kekuasaan penjajahan barat, menghadapi keadaan demikian, nampaknya ummat islam terbagi dalam tiga kelompok dengan sikap yang berbeda pila,

a. Mereka yang menutup diri dan pengaruh modernisasi barat.

b. Mereja yang membuka diri terhadap modernisasi barat.

c. Mereka yang membuka modernisasi barat dengan penuh selektif.

Ketiga bentuk pembaharuan merambat masuk kedalam dunia pendidikan islam. Akhirnya lahirlah pola-pola pembaharuan pendidikan islam, yaitu sebagai berikut:

2 Dr. Abdur Rahman Assegaf, MA, Pendidikan Islam Di Indonesia, (Yogyakarta: Suka Press 2007), hlm.94 
1. Pola yang berorientasi pada pendidikan modren di eropa

Pola ini di upayaka untuk mengambil alih segala bentuk perkembangan ilmu pengetahuan dan teknologi yang ada di barat. Hal ini di lakukan, karena menurut golongan ini, kemajuan dunia barat sekarang di sebabkan mereka mewarisi kemajuan yang pernah di miliki oleh ummat islam dimasa jayanya. Maka dari itu tidaklah salah apabila kita juga bersikap sebagai mana orang barat dulu bersikap tehadap kemajuan dunia islam.

2. Pola yang berorientasi pada pemurnian kembali ajaran islam

Ummat harus kembali pada ajaran yang asli yang bersumberkan pada alquran dan hadist tanpa di tambah ataupun di kurangi. Yang menjadi ciri khas gerakan ini adalah tajdid terletak pada kemampuan akal maka pengetahuan medren yang lebih menyadarkan pada akal harus di pelajari di samping pengetahuan tradisional. Sebagai tema sentral adalah menolaktaklid.

3. Pola yang berorientasi pada nasionalisme dan kekayaan budaya bangsa masing-masing.

Adanya pemahaman bahwa ajaran islam dapat diterapkan sesuai dengan kondisi, waktu, dan tempat, melahirkan pemikiran untuk berupaya memperbaiki ummat islam dengan memerhatikan kondisi onjektif ummat islam itu tempat ia berada.

Dengan demikian, kita ketahui bahwa permulaan abad ke-20, merupakan masa pertumbuhan dan perkembangan madrasah hampir di seluruh indonesia, dengan nama dan tingkatan yang bervariasi. Namun madrasah-madrasah tersebut pada awal perkembanganya, masih bersifat diniyah semata-mata. Dalam memantapkan keberadaanya dilakukanlah pembaharuan terhadap madrasah, khususnya dengan penambahan pengetahuan umum.

Usaha ke arah penyatuan dan penyeragaman sistem tersebut baru di rintis sekitar tahun 1950 setelah indonesia merdeka. Pada perkembanganya, madrasah terbagi dalam jenjang-jenjang pendidikan, madrasah ibtidaiyyah, madrasah tsanawiyah, dan madrasah aliyah. 
Dengan keterangan tersebut dapat di pahami Bahwa madrasah tersebut adalah penekananya sebagai suatu lembaga yang mengajarkan ilmu-ilmu keislaman. Perkataan madrasah di tanah arab ditujukan untuk semua sekolah secara umum, akan tetapi di indonesia di tujukan buat sekolah-sekolah yang mempelajari ajaran-ajaran islam. Madrasah pada prinsipnya adalah kelanjutan dari sistem pesantren. ${ }^{3}$

Tumbuh dan berkembangya madrasah di indonesia tidak dapat dipisahkan dengan tumbuh dan berkembangnya ide-ide pembaruan dikalangan umat islam. Di permulaan abad ke-20 timbul beberapa perubahan bagi umat islam indonesia.

Diantara ulam yang berjasa dalam menggagas timbulnya madrasah di indonesia antara lain Syekh Abdullah Ahmad, pendiri madrasah Adabiyah di padang pada tahun 1909. Pada tahun 1915 madrasah ini menjadi HITS Adabiyah yang tetap mengajarkan agama. ${ }^{4}$

Pendidikan di madrasah atau lembaga pendidikan lain, kesenjanagan pengetahuan anak-anak di jawa dan di luar jawa secara ratarata, memerlukan semua pihak. Selama ini, lembaga pendidikan islam seperti madrasah dan pesantren tampak jelas tertinggal dari kemajuan pembangunan. ${ }^{5}$

Menurut keterangan maksum (1999) madrasah di indonesia masih bisa di anggap sebagai perkembangan lanjut atau pembaharuan dari lembaga pendidikan pesantren dan surau. Menari untuk di catat bahwa di ukur dari ketentuan-ketentuan fisik pada abad 11-12 M struktur pesantren agaknya menyerupai madrasah di bagdad abad 11-12.

\section{PEMBAHARUAN MADRASAH DI INDONESIA}

\footnotetext{
${ }^{3}$ Prof. Dr.H. Haidar Putra Daulay, MA, Sejarah Dan Pertumbuhan Pendidikan Islam, (jakarta: kencana, 2007) hlm. 93

${ }^{4}$ Ibid, hlm. 96

${ }^{5}$ Prof. Dr. Zakiyah Drajat, Perkembangan psikologi agama dan pendidikan islam Di indonesia, (Ciputat: Logos wacana ilmu, 1999),hlm. 90
} 
Madrasah sebagai institusi pendidikan keagaman di indonesia memiliki sejarah panjang. Pada zama penjajahan belanda, madrasah didrikan untuk semua warga. Sejarah mencatat, madrasah pertama kali berdiri di sumatra, madrasah adabiyah 1908, di motori syek abdullah ahmad, tahun 1910 berdiri madrasah schol di batu sangkar oleh syaik M. Taib umar, kemudian M mahmud yunus pada 1918 mendirikan diniyah schoel sebagai lanjutan dari madrasah schoel. Madrasah tawalib didirikan syek abdul karim amrullah di padang panjang 1907 lalu madrasah Nurul Uman didirikan H Abdul somad di jambi.

Madrasah berkembang di jawa mulai 1912. Ada model madrasahpesantren NU dalam bentuk madrasah aliyah, ibtidaiyah, Tsanawiyah, muallimin wustha, dan muallimin ulya.

\section{E. SISTEM PENDIDIKAN DAN PENGAJARAN DI MADRASAH}

Perpaduan antara sistem pada pondok pesantren atau pendidikan langgar dan sistem yang berlaku pada sekolah-sekolah modern merupakan sistem pendidikan dan pengajaran yang dipergunakan di madrasah. Proses perpaduan tersebut berangsur-angsur dan mengikuti sistem klasikal. Sistem pengajian kitab yang selama ini dilakukan, di ganti dengan bidangbidang pelajaran tertentu, walaupun masih menggunakan kitab-kitab yang lama.

Bahkan, kemudian lahirlah madrasah-madrasah yang mengikuti sistem perjenjangan dan bentuk-bentuk sekolah modren, seperti madrasah ibtidaiyyah sama dengan sekolah dasar(SD), madrasah Tsanawiyah sama dengan sekolah menengah pertama(SMP), dan Madrasah Aliyah sama dengan sekolah menengah Atas(SMA).

Kurikulum madrasah dan sekolah-sekolah agama masih mempertahankan agama sebagai mata pelajaran pokok, walaupun dengan persentase yang berbeda. Pada waktu pemerintah republik indonesia, kementerian agama yang mengadakan pembinaan dan pengembangan terhadap sistem pendidikan madrasah melalui kementrian agama, merasa 
perlu menentukan kriteria madsarah. Kriteria yang di tetapkan oleh mentri agama untuk madrasah-madrasah yang berada dalam wewenagnya adalah harus memberikan pelajaran agama sebagai mata pelajaran pokok, paling sedikit 6 jam seminggu.

Pemgetahuan umum yang di ajarkan dimadrasah adalah:

1. Membaca dan menulis(huruf latin) bahasa indonesia.

2. Berhitumg.

3. Ilmu bumi.

4. Sejarah indonesia dan dunia.

5. Olah raga dan kesehatan.

Selain mata pelajaran agama dan bahasa arab serta yang di sebutkan di atas, juga di ajarkan sebagai keterampilan sebagaki bekal para lulusanya terjun ke masyarakat.

\section{F. PEMBINAAN DAN PENGEMBANGAN MADRASAH}

Pendidikan dan pengajaran merupakan suatu kewajiban yang tegas-tegas menjadi ketentuan dalam islam bagi pemeluknya, sehingga sebagai condition a sine qua non yang harus dilaksanakan oleh umat islam tanpa kecuali maju mundurnya, jatuh dan bangunya, besar kecilnya peran islam sangat bergantung pada berhasil tidaknya pendidikan dan pengajaran yang di lancarkan.

Madrasah dan pesantren yang pada hakikatnya merupakan salah satu alat dan sumber pendidikan serta pencerdasan rakyat jelata yang sudah berurat berakar dalam masyarakat indonesia umumnya, hendaklah mendapat perhatian dan bantuan yang nyata berupa tuntunan dan bantuan materil dari pemerintah.

Berdasarkan ketentuan tersebut, jenjang pendidikan pada madrasah tersusun sebagai berikut:

1. Madrasah rendah atau sekarang lazim di kenal sebagai madrasah ibtidaiyyah, ialah madrasah yang memuat pendidikan dan ilmu 
pengetahuan agama islam menjadi pokok pengajaranya, lama pendidikan 6 tahun.

2. Madrasah lanjutan tingkat petama atau sekarang di kenal sebagai ,adrasah tsanawiyahialah madrasah yang menerima murud-murid tamatan madrasah rendah atau sederajat dengan itu, serta emberi pendidikan dalam ilmu pengetahuan agama islam sebagai pokok, lama pendidikanya 5 tahun.

3. Madrasah lanjutan atas atau sekarang di kenal sebagai madrasah aliyah, ialah madrasah yang menerima murid-murid tamatan madrasah lanjutan pertama atau yang sederajat memberikan pendidikan dalam ilmu pengetahuan agama islam sebagai pokok lama belajar selama 3 tahun.

Disamping pendidikan agama, madrasah tersebut memberikan pengajaran umum sekurang-kurangnya $30 \%$ dari jumlah jam pengajaran seluruhnya seminggu.

Bentuk pendidikan melalui madrasah, selain tetap memenuhi harapan bagi pembekalan pengetahuan keislaman pada para siswaanya, juga dimaksutkan unruk meberikan wawasan pengetahuan umum dan pembekalan yang diperlukan untuk dapat menjalankan berbagai peran dalam kehidupan didunia modern.

Pembentukan madrasah, sebagai salah satu bentuk lembaga pendidikan islam di luar pesantren yang tidak seluruhnya menerapkan kurikulum keislaman dan yang menerapkan sistem klasikal, juga membawa perubahan terhadap otoritas kyai dilembaga pendidkan islam. Madrasah tidak menerapkan manajemen pendidikan dengan otoritas. Hal itu juga berlaku pada kebanyakan madrasah swasta yang didirikan atas dukungan kyai dan elemen masyrakat lainnya. ${ }^{6}$

\section{G. MADRASAH WAJIB BELAJAR}

${ }^{6}$ Dr. Nurhayati Djamas, M.A, Dinamika Pendidikan Islam Di Indonesia, (Jakarta:rajawali pers, 2009),hlm. 205 
Sudah cukup lama departemen agama berkeinginan untuk memodrenkan dunia madrasah, pesantren, dan pengajian, sesuai dengan dasar dan cita-cita pendidikan indonesia. Diantara usaha yang dilakukan untuk terealisasinya keinginan tersebut ialah dengan mengadakan pembaharuan secara revolusioner dalam bidang pendidikan madrasah. Pembaharuan itu terwujud dalm bentuk yang di beri nama madrasah wajib belajar, yang mulai di lakukan pada tahun pelajaran 1958/1959. ${ }^{7}$

Dilaksanakanya madrasah wajib belajar ini adalah dengan tujuan:

a. Turut berusaha dalm rangka pelaksanaan undang-undang wajib belajar di indonesia. Mempunyai hak dan kewajiban sebagai sekolah negeri atau sekolah partikelir yang melaksanakan wajib belajar.

b. Pendidikan sekali di arahkan kepada pembangunan jiwa bangsa untuk mencapai kemajuan di lapangan ekonomi, industrialisasi, dan transmigrasi.

Dari rangkaian di atas sturuktur tersebut di atur sebagai:

a. MWB adalah tangggung jawab pemerintah baik mengenai guru-guru, alat-alat, maupun buku-buku pelajaranya, apabila madrasah memenuhi persyaratan yang ditentukan untuk dijadikan MWB.

b. Menampung murid-murid yang berumur antara 6-14 tahun. Tujuanya adalah untuk mempersiapkan mutu murid untuk dapat hidup mandiri dan mencari nafkah, terutama dalam lapangan ekonomi.

c. $25 \%$ dari jumlah jam pelajaran digunakan untuk pelajaran agama, sedang $75 \%$ untuk pelajaran pengetahuan umum dan kerajinan tangan.

Dilaksanakanya madrasah wajib belajar tersebut, dimaksudkan sebagai usaha awal untuk memberikan bantuan dan pembinaan madrasah dalam rangkan penyelenggaraan materi kurikulum dalam upanya peningkatan mutu madrasah ibtidaiyah.

Madrasah wajib belajar yang mulai di selenggarakan pada tahun pelajaran 1958 dilaksanakan dengan tujuan :

${ }^{7}$ Drs. Hasbullah, Sejarah Pendidikan Islam di Indonesia, (Jakarta:PT Raja Grafindo persada, 1996),hlm.178 
Sesuai dengan namanya madrasah wajib belajar turut berusaha dalam rangka pelaksanaan undang-undang kewajiban belajar di indonesia. Dalam hubungan ini MWB mempunyai hak dan kewajiban sebagai sekolah negeri atau sekolah partikelir yang melaksanakan wajib belajar.

Madrasah diniyah terdiri dari tiga jenjang atau tingkatan yaitu:

1. Madrasah Diniyah Awaliyah: yaitu madrasah yang khusus mempelajari pengetahuan ilmu agama islam pada tingat dasar.

2. Madrasah Diniyah Wustho: yaitu yang khusus mengajarkan ilmu pengetahuan agama pada tingkat menengah pertama.

3. Madrasah Diniyah Aliyah: yaitu mengajarkan ilmu pengetahuan agama pada tingkat menengah atas.

Mengingat anak-anak yang menjalani pendidikanya di madrasah adalah anak-anak yang kurang mampu secara sosial dan ekonomi. Merekalah yang sesungguhnya memerlukan bantuan yang lebih besar dibanding mereka yang menjalani di sekolah umum negeri. Karena MI dan MTs adalah bagian dari sistem penyelenggaraan wajib belajar pendidikan sembilan tahun. Dikriminasi ini dapat berdampak kuatnya kesan bahwa anak-anak madrasah diperlakukan sebagai warga negara kelas kedua, sementara saudara-saudaranya yang lain di beri keistimewaan, dan memerlakukan semua anak indonesia sama dengan azas keadilan sosial. ${ }^{8}$

Madrasah dapat di aktualisasikan denngan menghadirkan tiga desain besar pendidikan madrasah: ${ }^{9}$

a. Madrasah unggulan

Madrasah unggulan di maksudkan sebagai center for excellence dan akan dikembangakan satu buah untuk tiap provinsi. Madrasah unggulan di proyeksikan sebagai wadah penampung putra-putra terbaik masing-masing daerah untuk didik secara maksimal tanpa harus pergi ke daerah lain

b. Madrasah model

${ }^{8}$ Ibid, hlm. 90

${ }^{9}$ http://googlewelinght.com/?liteursejarah munculnya madrasah .htm? 
madrasah model dimaksudkan sebagai center of excellence yang dikembangkan lebih dari satu buah untuk tiap provinsi. Madrasah model diproyeksikan sebagai wadah penampung pitra-putra terbaik masingmasing daerah untuk didik secara maksimal tanpa pergi ke daerah lain.

Sebagai mana pada madrasah unggulan, keberadaan madrsah model juga dapat mencegah terjadinya eksodus SDM terbaik suatu daerah ke daerah lain.

c. Madrasah reguler atau kejuruan

Madrasah yang fungsinya utamanya adalah memberikan pelanyanan pendidikan kepada setiap masyarakat tanpa terkecuali. Madrasah ini dibangun beberapa buah untuk tiap kabupaten sesuai dengan kebutuhan dengan dana dari pemerintah pusat dan pemerintah daerah tingkat. Yang pasti di setiap kecamatan terdapat minimal satu madrasah reguler/kejuruan. Sebagaimana jenis madrasah lainya. Madrasah reguler/kejuruan juga di perkuat oleh majelis madrasah yang secara aktif membantu pengembangan madrasah.

\section{H. KELAHIRAN KURIKULUM MADRASAH 1994}

Dengan diberlakukanya UU No. 2 tahun 1989 tentang sistem pendidikan nasional dengan segala peraturan pemerintah sebagai pedoman pelaksanaanya, kurikulum untuk jenjang dan jenis pendidikan yang sedang berlaku perlu di sesuaikan dengan peraturan perundang-undangan tersebut.

Pada pasal 37 UU No 1989 dinyatakan bahwa kurikulum disusun untuk mewujudkan tujuan pendidikan nasional dengan memerhatikan tahap perkembangan siswa dan kesesuainya dengan lingkungan, kebutuhan pembangunan nasional, perkembangan ilmu pengetahuan dan teknologi serta kesenian, dengan jenis dan jenjang masing-masing satuan pendidikan.

Sementara itu, pasal 4 ayat 3 peraturan pemerintah No. 28 tahun 1990 tentang pendidikan dasar mengatakan bahwa SD dan SLTP yang berciri khas agama islam yang diselenggarakan oleh departemen agama 
masing-masing disebut Madrasah ibtidaiyah (MI) dan madrasah Tsanawiyah (MTs).

Adapun mengenai madrasah Aliyah di sebut sebagi sekolah menengah umum, sebagaimana di kemukakan pada bab 1 pasal 1 ayat 6 bahwa: Madrasah Aliyah adalah sekolah menengah umum(SMU) yang berciri khas agama islam yang di selenggarakan oleh departemen agama.

Sebagai konsekuensi atas status dan keberadaan madrasah tersebut, disatu pihak madrasah memikul tanggung jawab sebagai lembaga pendidikan umum yang sama dengan sekolah-sekolah umumnya, sedangkan pada sisi lain, madrasah memiliki tanggung jawab sebagai lembaga pendidikan islam. Kondisi demikian akan lebih jelas bila dilihat dari perbandingan antara mata pelajaran agama dan mata pelajaran umum pada kurikulum madrasah 1994. Dengan posisi seperti ini, tanggung jawab madrasah akan jauh lebih berat dan besar dibandingkan dengan sekolahsekolah umum yang sederajat.

Diantara bagian isi pokok ketentuan-ketentuan tersebut ialah mengenai program pengajaran ditentukan bahwa setiap madrasah pada tingkat masing-masing wajib melaksanakan kurikulum matapelajaran yang disusun secara nasional.

Dari gambaran tersebut dapat kita lihat bahwa alokasi mata pelajaran agama di madrasahsangat sedikit. Oleh karena itu, jika berharap dari kurikulum muatan nasional untuk intrakurikuler ini saja, tentu tidak akan mungkin dapat memunculkan ciri khas madrasah dengan baik dan memiliki nilai tambahan dibanding lembaga pendidikan umum yang sederajat. Terlebi-lebih, untuk melahirkan orang-orang yang ahli dan menguasai pengetahuan agama islam secara mendalam.

Dalam kurikulum 1994 juga telah diatur kurikulum yang bersifat lokal dan ciri khas. Kurikulum yang bersifat lokal ini pada dasarnya ditentukan sendiiri oleh masing-masing lembaga pendidikan atau pihakpihak lain yang berlaku sebagai berikut: 
"madrasah dapat menambah mata pelajaran sesuai dengan keadaan lingkunganya dan ciri khas madrasah yang bersangkutan dengan tidak mengurangi kurikulum yang berlaku secara nasional dan tidak menyimpang dari tujuan pendidikan. Madrasah juga dapat menjabarkan dan menambah bahan kapan dan mata pelajaran sesuai dengan kebutuhan setempat.

Berdasarkan ketentuan tersebut, dapat di mengerti bahwa kurikulum lokal dan kurikulum ciri khas dapat di kembangkan pada madrasah sepanjang ketersediaan waktu dan kesempatan masih memungkinkan dengan tidak boleh mengurangi dan bertentangan dengan kurikulum yang di atur secara nasional. Diantara bagian dari isi pokok ketentuan-ketentuan tersebut adalah mengenain program pengajaran. Dimana di tentukan bahwa setipa madrasah pada tingkatan madrasah pada tingkatan masing-masing wajib melaksanakan kurikulum mata pelajara yang di susun secara nasional.

\section{POSISI MADRASAH DI TENGAH TUNTUNAN KUALITAS}

Madrasah sebagai lembaga pendidikan yang berciri khas Islam banyak menarik perhatian berkenaan dengan cita-cita pendidikan nasional. Hal itu disebabkan karena jumlah peserta didiknya yang signifikan, akan tetapi juga karena karakteristiknya yang sesuai dengan perubahan dan perkembangan zaman.

Keberadaan madrasah menjadi sangat menonjol oleh karena; pertama, pendidikan di madrasah selama ini seakan-akan tersisih dari mainstream pendidikan nasional, sekalipun berkenaan dengan pendidikan anak bangsa. Kedua, madrasah sebagai pendatang baru dalam sistem pendidikan nasional relatif menghadapi berbagai kendala dalam hal mutu, manajemen, dan kurikulumnya. Namun demikian, madrasah masih mempunyai banyak potensi atau nilai-nilai positif yang dapat di kembangkan. ${ }^{10}$

${ }^{10}$ Prof. Dr. Suwito, MA, Sejarah Sosial Pendidikan Islam, (Jakarta: kencana prenada media group,2008). hlm.223 
Madrasah pada umumnya didirikan oleh masyarakat, dimana para pengelola dan komunitas pendukung itulah yang menentukan visi dan misinya apakah lembaga pendidikan tersebut mempunyai keinginan untuk maju. Madrasah juga merupakan jenis pendidikan yang memberikan perhatian dan sekali gus menjadikan ajaran islam sebagai pengetahuan untuk program studi yang diselenggarakanya.

Madrasah merupakan lembaga pendidikan yang lahir dari, dan untuk masyarakat. Keluhan tentang kualitas pendidikan di madrasah selalu bukan tentang pendidikan agama yang kurang, namun lebih kepada kurangnya pendidikan umum yang tidak setaraf dengan sekolah umum dan tidak mempunyai efek sosial dalam masyarakat.

\section{J. MADRASAH SEBAGAI LEMBAGA PENDIDIKAN ISLAM}

Menurut peraturan mentri agama nomor I tahun 1946 danperaturan mentri agama nomor 7 tahun 1950, madrasah mengandung makna.

a. Tempat pendididkan yang di atur sebagai sekolah dan membuat pendidikan dan ilmu pengetahuan ilmu agama islam menjadi pokok pengajaranya.

b. Pondok dan pesantren yang memberi pendidikan setingkat dengan madrasah.

Sistem dan isi madrasah di upayakan adanya penggabungan antara siste

pesantren dengan sekolah umum. Madrasah sebagai perpaduan antara pendidikan sistem pondok yang khusus mengajarkan agama islam dengan sistem pendidikan yang mengajarkan ilmu umum.

Sejak lahirnya sistem madrasah di indonesia. Telah memiliki ciri khas yang membedakanya dari pesantren dan sekolah umum. Walaupun keanekaragaman dalam upanya menggabungkan antara mata pelajaran agama dengan mata pelajaran umum, namun madrasah tetap sebagai lembaga pendidikan islam yang menjadikan mata pelajaran agama sebagai mata pelajaran pokok atau dasar. 
Sturktur program kurikulum madrasah aliyah pada tahun1984 pendidikan agama terdiri dari mata pelajaran.

a. Quran hadist

b. Akidah Akhlak

c. Fikih

d. Sejarah dan peradaban islam

e. Bahasa arab, semua semua mata pelajaran ini di golongkan pada program inti.

Berikut materi pelajaran yang mencakup dari perkelas mulai dari kelas satu sebagai berikut:

a. Mencakup huruf hijaiyyah yang sesuai dengan huruf tajwid al-quran.

b. Menulis huruf hijaiyyah

c. Memahami ilmu hitung

d. Membiasakan akal, dan pengertian adab

Kelas dua berisi materi:

a. Ilmu aqa'id, ilmu akhlak dan ilmu fiqih.

b. Mutolaah dan mengarang dengan bahasa arab.

c. Menulis halus (khat) Arab.

kelas tiga yang berisi materi:

a. Ilmu bahasa arab.

b. Ilmu bahasa inggris.

c. Geografi.

d. Dan ilmu mengarang dan berpidato. ${ }^{11}$

Kita berharap dalam era indonesia baru. Kita mendambakan bahwa madrasah sebagai lembaga pendidikan yang populis, islami, dan berorientasi pada mutu dapat membekali pengetahuan, keterampilan dan kemampuan bagi anak-anak bangsa dari kalangan yang tertinggal untuk menjadi anak yang maju. Madrasah dapt menjadi jendela bagi anak desa menjadi anak kota, yang kemudian menjadi anak yang berwawasan

${ }^{11}$ Muh. Saerozi, Pembaharuan Pendidikan Islam, ( yogyakarta:tiara wacana 2013). hlm.151 
regional, dan global dan tetap berpangkal pada jati diri mereka yang lokal. Karena itu, madrasah adalah wahana pemberdayaan anak-anakn tertinggal untuk secara pasdan berimbang membangun perkaitan dan pertautan tumpang tindihnya antara yang lokal, ptovinsial, nasional, regional, dan global. ${ }^{12}$

Sistem pembelajaran madrasah tsanawiyah, pertama mengembangkan kemampuan berkomunikasi menyimak dan menulis. Kedua sebagai salah satu bahasa asing menjadi alat utama belajar. Ketiga memiliki wawasan lintas budaya dan dalam keragaman berbudaya. Sistem pembelajaran madrasah aliyah, pertama menyimak, membaca dan mengembangkan. Kedua sebagai salah satu bahasa asing. ${ }^{13}$

\section{Kesimpulan}

Keberadaan madrasah menjadi sangat menonjol oleh karena; pertama, pendidikan di madrasah selama ini seakan-akan tersisih dari mainstream pendidikan nasional, sekalipun berkenaan dengan pendidikan anak bangsa. Kedua, madrasah sebagai pendatang baru dalam sistem pendidikan nasional relatif menghadapi berbagai kendala dalam hal mutu, manajemen, dan kurikulumnya. Namun demikian, madrasah masih mempunyai banyak potensi atau nilai-nilai positif yang dapat di kembangkan.

Madrasah pada umumnya didirikan oleh masyarakat, dimana para pengelola dan komunitas pendukung itulah yang menentukan visi dan misinya apakah lembaga pendidikan tersebut mempunyai keinginan untuk maju. Madrasah juga merupakan jenis pendidikan yang memberikan perhatian dan sekaligus menjadikan ajaran Islam sebagai pengetahuan untuk program studi yang diselenggarakanya.

\footnotetext{
12 Ibid. hlm. 91

${ }^{13}$ Heri Gunawan, S.Pd.I, Kurikulum Pembelajaran Pendidikan Islam, (Bandung:Alfabeta, 2012), hlm. 209
} 


\section{DAFTAR PUSTAKA}

Dra. Hj. Enung K Rukianti. Sejarah Pendidikan Islam. Bandung: CV pustaka setia. 2006

Heri Gunawan. S.Pd.I. Kurikulum Pembelajaran Pendidikan Islam. Bandung: Alfabeta. 2012

Muh. Saerozi. Pembaharuan Pendidikan Islam. yogyakarta:tiara wacana 2013.

http://googlewelinght.com/?liteursejarah munculnya madrasah .htm?

Prof. Dr. Suwito.MA. Sejarah Sosial Pendidikan Islam. Jakarta: kencana prenada media group.2008.

Dr. Nurhayati Djamas. M.A. Dinamika Pendidikan Islam Di Indonesia, Jakarta:rajawali pers.2009.

Drs. Hasbullah. Sejarah Pendidikan Islam di Indonesia. Jakarta:PT Raja Grafindo persada. 1996.

Prof. Dr. Zakiyah Drajat. Perkembangan psikologi agama dan pendidikan islam Di indonesia.Ciputat: Logos wacana ilmu. 1999.

Prof. Dr.H. Haidar Putra Daulay, MA. Sejarah Dan Pertumbuhan Pendidikan Islam. jakarta: kencana. 2007.

Dr. Abdur Rahman Assegaf. MA. Pendidikan Islam Di Indonesia. Yogyakarta: Suka Press 2007. 